\title{
The Effect of Financial Ratios on Company Value in Oil and Gas Mining Subsectors in Indonesia Stock Exchange
}

\author{
Muhammad Ardian \\ Student of Master of Management, Faculty of Economics, Sriwijaya University, Indonesia \\ Corresponding author email: muhammad.ardian.mm@gmail.com \\ Mohammad Adam \\ Lecturer in Management Department, Faculty of Economics, Sriwijaya University, Indonesia \\ Email:mr_adam2406@yahoo.com \\ Marlina Widiyanti \\ Lecturer in Management Department, Faculty of Economics, Sriwijaya University, Indonesia \\ Email: marlinawidyanti68@yahoo.co.id \\ Isnurhadi \\ Lecturer in Management Department, Faculty of Economics, Sriwijaya University, Indonesia \\ Email: isnurhadi2020@gmail.com
}

\begin{abstract}
Firm value is influenced by elements outside and within the organization. . They were selected by purposive examination technique. The examination procedure used is Panel Data Regression Analysis. The consequences of such examinations lead to the demonstration that Return on Equity has a substantial beneficial return on firm value, suggesting that return on capital through increased benefits will build financial support certainty. Conversely, the Debt to Asset Ratio has a critical negative impact on firm value. This implies that the use of extreme liabilities can sustain the business. Owners and top administrative organizations should be careful about the use of obligations. Operational productivity and expansion of the number of items must be the primary concern to build Return on Equity. Different factors, such as Asset Growth, Total Asset Turn Over, and Current Ratio, have no impact on firm value.
\end{abstract}

Keywords---asset growth, financial ratios, firm value.

\section{Introduction}

In the business world, the two foundations and people, different endeavors are made to build up their organizations. Business improvement requires extra capital, which should be possible with ventures from outside the organization. The capital market is a decent method for organizations that need assets or capital or financial backers who will contribute. The view of speculation can be impacted by the estimation of the organization. Organizational esteem helps pull in financial backers to put resources into the organization concerned. Boosting organization esteem is the organization's objective to flourish the investors or financial backers of the organization's offers.

The oil and gas industry is one of the subsectors which at first pulled in numerous financial backers. The good and bad times of speculation interest in the oil and gas industry are impacted by outer and interior variables. Outside elements as world financial conditions and fluctuating oil and gas cost extraordinarily influence the speculation environment in the oil and gas industry. In mid-2014, world oil costs would in general decay with the expansion in the stockpile from Shale Oil starting from the United States bringing about unevenness in inventory interest. Even though there is right now a decrease in world oil costs, the potential for oil and gas in Indonesia is assessed to be 
very enormous. Dwi Sutjipto (Head of the Special Task Force for Upstream Oil and Gas Business Activities) that the potential for Indonesian oil and gas to arrive at 8.3 billion barrels has not been investigated (Indrawan, 2019). What's more, this potential draws in light of a legitimate concern for financial backers and the factor of world energy request is still very high.

Firm worth is likewise impacted by the organization's monetary condition which can be estimated through monetary proportion examination. The organization's esteem proxied in this examination as the Price to Book Value Ratio (PBV). Sari \& Dwirandra (2019) expressed: "Not all stocks from companies that have a good profile will provide good returns to investors, so a more in-depth analysis of the company is needed. One way is to do a fundamental analysis based on financial ratios." (Lindayani \& Dewi, 2016; Cinca et al., 2005; Öcal et al., 2007). It is trusted that this monetary proportion data can be a benchmark for amplifying organization esteem. This is additionally upheld by the assertion of Widiyanti, (2014) which states: "Data as monetary proportions is a reference for financial backers to break down various business wonders". A few organizations in a similar area can be evaluated for their exhibition through estimation of monetary proportions.

Castelnuovo \& Pellegrino (2018) states that monetary proportion investigation can be characterized into 6 gatherings, specifically: Liquidity Ratios, Solvency Ratios, Activity Ratios, Profitability Ratios, Growth Ratios, and Assessment Ratios (Lev \& Sunder, 1979; Lewellen, 2004; Wiklund et al., 2010). Monetary proportions will give data about the genuine condition of the organization which shows a sign of the qualities and shortcomings of an organization. In this investigation, 5 monetary proportion factors were estimated through a few proxied factors, in particular: Asset Growth. Return On Equity, Total Asset Turnover, Debt to Asset Ratio, and Current Ratio.

Table 1

Normal information of PBV, AG, ROE, TATO, DAR, and CR of Oil and Gas Mining Subsector Companies Listed on the IDX for the 2014-2019 period

\begin{tabular}{cccccccc}
\hline \multirow{2}{*}{ No } & \multirow{2}{*}{ Ratio } & \multicolumn{7}{c}{ Year } \\
\cline { 3 - 8 } & & 2014 & 2015 & 2016 & 2017 & 2018 & 2019 \\
\hline 1 & PBV (x) & 0,98 & 0,76 & 0,50 & $-1,80$ & 0,22 & 0,57 \\
\hline 2 & AG (x) & 0,13 & 0,13 & 0,14 & 0,11 & 0,09 & 0,06 \\
\hline 3 & ROE (x) & 0,09 & $-0,02$ & 0,22 & $-0,58$ & 0,03 & $-0,003$ \\
\hline 4 & TATO (x) & 0,32 & 0,34 & 0,30 & 0,27 & 0,23 & 0,26 \\
\hline 5 & DAR (x) & 0,53 & 0,54 & 0,59 & 0,64 & 0,63 & 0,63 \\
\hline 6 & CR (x) & 1,65 & 1,49 & 2,87 & 1,68 & 1,75 & 1,44 \\
\hline
\end{tabular}

In past exploration that has been completed with the examination of a few monetary proportion factors that are assessed to influence firm esteem. Cho \& Pucik (2005), Kuzey et al. (2014), Aggarwal \& Padhan (2017), and Khairunnisa et al. (2018) presumed that Asset Growth will affect the Price to Book Value Ratio. In the meantime, as indicated by Hasbi (2015), (Triyani et al., 2018) contends that Asset Growth has no impact on the Price to Book Value Ratio.

The expansion in productivity will give financial backers trust in the organization which will affect the increment in organization esteem. In Varaiya et al. (1987), Cho \& Pucik (2005) states that Return On Equity will impact the Price to Book Value Ratio, while Chen \& Zhao (2006), Khairunnisa et al. (2018) expressed that Return On Asset negatively affects the Price to Book Value Ratio. Kuzey et al. (2014), Asiri \& Hameed (2014), Misran \& Chabachib, (2017) contend that a positive impact will be brought about by the Total Asset Turn Over factor on the Price to Book Value Ratio. In the meantime, Hendrick (2020) states that the consequences of his examination show that the negative impact of Total Asset Turn Over on the Price to Book Value Ratio.

In the exploration of Ghalandari (2013), Obreja (2013) expresses that the Debt to Asset Ratio positively affects the Price to Book Value Ratio. While the aftereffects of the examination by Chen \& Zhao (2006), Aggarwal \& Padhan (2017) show that the connection between Debt to Asset Ratio and Price to Book Value Ratio will have a negative impact. Khodamipour et al. (2014) in their examination expressed that the Current Ratio (CR) impacts firm worth. Aggarwal \& Padhan (2017) presumed that the Current Ratio (CR) negatively affects firm worth. Kuzey et al. (2014) and in their exploration contend that Current Ratio (CR) has no impact on the firm worth. 


\section{Method}

Is auxiliary information sourced from quarterly monetary reports and offer costs from mining organizations in the oil and gas mining subsector from 2014-2019 which are recorded on the Indonesia Stock Exchange. The utilization of purposive examining procedure to acquire 7 organizations that meet the rules with an aggregate of 168 information. This examination is a quantitative report utilizing the board information relapse investigation technique. Assurance of this board information relapse condition through board information model assessment. There are three assessment strategies, specifically: Common Effect Model, Fixed Effect Model, and Random Effect Model which is completed with the Eviews 9 program. The type of model to be tried in this investigation are:

$$
\mathrm{PBV}_{i t}=\alpha+\beta_{1} \mathrm{AG}_{i t}+\beta_{2} \mathrm{ROE}_{i t}+\beta_{3} \mathrm{TATO}_{i t}+\beta_{4} \mathrm{DAR}_{i t}++\beta_{5} \mathrm{CR}_{i t}+\square \mathrm{it}
$$

\section{Research Result}

The results of the Panel Data Regression Model Selection Test through the Chow Test, the Hausman Test, and the Lagrange Multiplier Test, the chosen equation model is the Common Effect Model, then the regression equation results will be obtained as follows:

$$
\mathrm{PBV}_{i t}=2,689951+0.817388 \mathrm{AG}_{i t}+2.938688 \mathrm{ROE}_{i t}-0.380334 \mathrm{TATO}_{i t}-3.575196 \mathrm{DAR}_{i t}+-0.1156 \mathrm{CR}_{i t}+\square \mathrm{it}
$$

Table 2

\begin{tabular}{|c|c|c|c|c|}
\hline \multicolumn{5}{|c|}{$\begin{array}{l}\text { Dependent Variable: PBV } \\
\text { Method: Panel Least Squares } \\
\text { Date: 01/18/21 Time: 09:49 } \\
\text { Sample: } 201401201904 \\
\text { Periods included: } 24 \\
\text { Cross-sections included: } 7 \\
\text { Total panel (balanced) observations: } 168\end{array}$} \\
\hline Variable & Coefficient & Std. Error & t-Statistic & Prob. \\
\hline $\begin{array}{l}\text { C } \\
\text { AG } \\
\text { ROE } \\
\text { TATO } \\
\text { DAR } \\
\text { CR }\end{array}$ & $\begin{array}{r}2.689951 \\
0.817388 \\
2.938688 \\
-0.380334 \\
-3.575196 \\
-0.115600\end{array}$ & $\begin{array}{l}0.588537 \\
0.515873 \\
0.091074 \\
0.460864 \\
0.818202 \\
0.072836\end{array}$ & $\begin{array}{r}4.570573 \\
1.584476 \\
32.26688 \\
-0.825262 \\
-4.369574 \\
-1.587125\end{array}$ & $\begin{array}{l}0.0000 \\
0.1150 \\
0.0000 \\
0.4104 \\
0.0000 \\
0.1144\end{array}$ \\
\hline
\end{tabular}

Results of panel data regression statistical processing

Model F-Test

Given the consequences of information preparing (the table over), the F-measurement esteem is 221.9348 with a likelihood of 0.0000 under 0.05 , which implies that $\mathrm{H} 0$ is dismissed and $\mathrm{H} 1$ is acknowledged, which implies the free factors (Asset Growth, Return On Equity, Total Asset Turn Over, Debt) to Asset Ratio, and Current Ratio) simultaneously affect Price to Book Value (PBV) or firm worth.

\section{Halfway Significance Test (t-test)}

From the consequences of the board information relapse condition and the table above, it tends to be investigated as follows:

1) Resource Growth (AG)

2) From the consequences of the fractional t-test on Asset Growth (AG), the t-tally esteem is 1.584476 with a likelihood of 0.1150 which has worth more prominent than 0.05, which implies that Asset Growth (AG) has no impact on Price to Book Value (PBV).

3) Return On Equity (ROE)

4) From the consequences of the halfway t-test on Return On Equity (ROE), the t-esteem is 32.26688 with a likelihood of 0.0000 , this likelihood figure is under 0.05, which implies that the variable Return on Equity (ROE) significantly affects Price to Book Value (PBV) somewhat. A positive number demonstrates that an increment in Return On Equity (ROE) will build the Price to Book Value (PBV). 
5) Absolute Asset Turn Over (TATO)

6) The aftereffects of the halfway t-test on Total Asset Turn Over (TATO) got t-tally estimation of - 0.825262 with a likelihood of 0.4104 which is more noteworthy than the number 0.05 which implies that the Total Asset Turn Over (TATO) variable has no impact on the Price to Book Value ( PBV) mostly.

7) Obligation to Asset Ratio (DAR)

8) From the table over, the consequences of the halfway t-test on the Debt to Asset Ratio (DAR) acquired t-check estimation of - 4.369574 with a likelihood of 0.0000 under 0.05, which implies that the variable Debt to Asset Ratio (DAR) significantly affects Price to Book Value ( PBV) on a fractional premise, anyway each increment in the Debt to Asset Ratio (DAR) variable will diminish the Price to Book Value (PBV) or organization esteem.

9) Current Ratio (CR)

10)From the consequences of the fractional t-test on the Current Ratio (CR), the t-check esteem is - 1.587125 with a likelihood of 0.1144 , which implies that the number is more prominent than 0.05 so it implies that the Current Ratio (CR) has no impact on the Price to Book Value (PBV) somewhat.

Coefficient of Determination (R2)

Table 3

The aftereffects of the assurance coefficient test (R2) are as per the following

\begin{tabular}{||lrll|}
\hline \hline R-squared & 0.872609 & Mean dependent var & 0.203113 \\
Adjusted R-squared & 0.868677 & S.D. dependent var & 5.496320 \\
S.E. of regression & 1.991785 & Akaike info criterion & 4.251000 \\
Sum squared resid & 642.6874 & Schwarz criterion & 4.362570 \\
Log likelihood & -351.0840 & Hannan-Quinn criter. & 4.296281 \\
F-statistic & 221.9348 & Durbin-Watson stat & 1.392146 \\
Prob(F-statistic) & 0.000000 & & \\
\hline
\end{tabular}

From the table over, the coefficient of assurance R2 is 0.872609 and Adjusted R2 is 0.868677 , which shows that the free factor can all the while clarifying $86.87 \%$ of its impact on the needy variable, in particular, Price to Book Value (PBV) and the leftover $13.13 \%$ is affected by different factors. outside of this exploration.

\section{Discussion}

Fractional impact of autonomous factors:

a. The Effect of Asset Growth on Firm Value

The consequences of the measurable examination of the Asset Growth variable have no impact on the firm worth. This is conceivable because a large portion of the resources claimed by the organization come from advances or obligations from outside gatherings or financial backers that surpass their capital. This unquestionably repudiates Cho's exploration. Kuzey et al. (2014), Aggarwal \& Padhan (2017), and Khairunnisa et al. (2018) express that Asset Growth positively affects firm worth.

b. Impact of Return on Equity on Firm Value

The table of exploration results for the variable Return on Equity significantly affects firm worth. The aftereffects of the examination show that each 1 expansion in Return On Equity will build the organization esteem by 2.938688. This variable additionally shows the connection between organization effectiveness endeavors and the utilization of organization resources that create overall gain with an end goal to expand firm worth. The consequences of this investigation are following past exploration, Cho \& Pucik (2005), Asiri \& Hameed (2014).

c. The Effect of Total Asset Turn Over on Firm Value

The absolute Asset Turn Over factor has no impact on the firm's worth. The state of the organization that may need to pay a few commitments and operational costs implies that the resources gathered from the improvement of deals results have no impact on organization esteem. This negates past examination, Cho \& Pucik (2005), Kuzey et al. (2014), Aggarwal \& Padhan (2017) expressed that Asset Growth positively affects firm worth.

d. Impact of Debt to Asset Ratio on Firm Value 
The variable Debt to Asset Ratio has a critical negative impact on the firm's worth. The consequences of this examination uncover that the more modest the Debt to Asset Ratio number, the better the firm's worth. The obligation is utilized as a wellspring of outer subsidizing when the organization's inner assets are deficient, which will influence the organization's worth on the off chance that it is utilized unreasonably and if the organization's income has diminished. The consequences of this investigation negate past exploration directed by Kuzey et al. (2014), Hong (2017) expressed that Debt to Equity positively affects the Price to Book Value Ratio.

e. The Influence of Current Ratio on Firm Value

This exploration shows that the organization's momentary commitments can be paid with current resources which can likewise come from the value or long haul obligation that is moved to pay transient obligation doesn't infer fortunate or unfortunate organization esteem. The consequences of this examination are unique concerning those of Aggarwal \& Padhan (2017) and Misran \& Chabachib (2017) presumed that the Current Ratio (CR) negatively affects firm worth.

\section{Simultaneous influence of independent variables}

Based on the research results, the Adjustable R2 coefficient of $86.8 \%$ can explain the effect of independent variables simultaneously on firm value. The dominance of the ROE variable with the rise and fall of the Return On Equity (ROE) variable quickly shows that income using own capital will have an impact on investors' perceptions of the company.

\section{Conclusion}

In this investigation, inspecting the impact of monetary proportions on firm worth shows the impact of proxied monetary proportion factors at the same time affecting firm worth. This exploration can be clarified in full as follows:

1) Monetary proportions that are proxied, in particular: Asset Growth, Return On Equity, Total Asset Turnover, Debt to Asset Ratio, and Current Ratio all the while showing a genuinely solid effect on endeavors to expand firm worth. Monetary proportions can give an evaluation of the organization's monetary condition with the goal that it is significant for financial backers to notice these monetary proportion factors.

2) Benefit proportions in this investigation are proxied by Return on Equity (ROE) which has the most effect on the firm's worth. Both from the organization the board and the financial backers, endeavors are made to screen this variable to give advantages to each gathering and endeavors to keep up the organization so it can keep on working appropriately through existing organization capital. The change of the productivity proportion will make the organization's esteem move similarly.

3) The dissolvability proportion that this examination intermediaries with the Debt to Asset Ratio (DAR) is likewise an answer for organizations to keep up the organization and endeavors to build pay through business openings or organization projects, however, the obligation utilized is hazardous for organizations with a commitment to pay their commitments. - organization's commitments to these obligations. The extreme obligation will lessen the estimation of the organization according to financial backers. Endeavors to keep up the organization by getting from outside gatherings or financial backers should be inspected by the organization the board so the business haggles incomes are not upset by such acquiring.

4) Development proportions, movement proportions, and liquidity proportions which are proxied in the Asset Growth, Total Asset Turn Over, and Current Ratio factors in this investigation, even though they all the while influence firm worth, they don't have a fractional impact.

Sign of Asset Growth through changes in organizational resources doesn't ensure that it will be following organization esteem. Complete Asset Turn Over (TATO), which is shown in the estimation of income per all-out resources utilized, doesn't ensure if the organization worth will increment. Also, the Current Ratio variable in satisfying momentary commitments doesn't make financial backers judge the organization to be working admirably. There is restricted information on organizations in the oil and gas mining subsector. For additional examination, it tends to be extended with the mining area which has more information, and in areas whose business execution is more steady so the outcomes are more precise. 


\section{Acknowledgments}

We, the authors, are grateful for the academic support from which parties and funding support the implementation of this study both from the start to its completion. The academic in question is the authorship and feedback process, which helps us during the review process to reporting. Once again, we appreciate it.

\section{References}

Aggarwal, D., \& Padhan, P. C. (2017). Impact of Capital Structure on Firm Value: Evidence from Indian Hospitality Industry. Theoretical Economics Letters, 7(4), 982-1000. https://doi.org/10.4236/tel.2017.74067

Asiri, B. K., \& Hameed, S. A. (2014). Financial ratios and firm's value in the Bahrain Bourse. Research Journal of Finance and Accounting, 5(7), 1-9.

Castelnuovo, E., \& Pellegrino, G. (2018). Uncertainty-dependent effects of monetary policy shocks: A newKeynesian interpretation. Journal of Economic Dynamics and Control, 93, 277-296.

Chen, L., \& Zhao, X. (2006). On the relation between the market-to-book ratio, growth opportunity, and leverage ratio. Finance Research Letters, 3(4), 253-266.

Cinca, C. S., Molinero, C. M., \& Larraz, J. G. (2005). Country and size effects in financial ratios: A European perspective. Global Finance Journal, 16(1), 26-47. https://doi.org/10.1016/j.gfj.2005.05.003

Cho, H.-J., \& Pucik, V. (2005). Relationship between innovativeness, quality, growth, profitability, and market value. Strategic Management Journal, 26(6), 555-575.

Ghalandari, K. (2013). The moderating effects of growth opportunities on the relationship between capital structure and dividend policy and ownership structure with firm value in Iran: Case study of Tehran securities exchange. Research Journal of Applied Sciences, Engineering and Technology, 5(4), 1424-1431.

Hasbi, H. (2015). Islamic microfinance institution: The capital structure, growth, performance and value of firm in Indonesia. Procedia-Social and Behavioral Sciences, 211, 1073-1080.

Hong, S. (2017). The effect of debt choice on firm value. Journal of Applied Business Research (JABR), 33(1), 135140.

Indrawan, R. (2019, April 30). Potensi Migas Capai 8,3 Miliar Barel Ditemukan di 19 Cekungan. Dunia Energi. https://www.dunia-energi.com/potensi-migas-capai-83-miliar-barel-ditemukan-di-19-cekungan/

Khairunnisa, T., Taufik, T., \& Thamrin, K. M. (2018). Pengaruh debt to equity ratio, return on assets, assets growth, current ratio, dan total assets turnover terhadap nilai perusahaan pada perusahaan sektor makanan dan minuman yang terdaftar di bursa efek indonesia [PhD Thesis]. Sriwijaya University.

Khodamipour, A., Golestani, S., \& Khorrami, M. (2014). The relationship between liquidity and the company size with company value in companies listed onthe Tehran Stock Exchange. European Online Journal of Natural and Social Sciences: Proceedings, $2(3$ (s)), pp-1210.

Kuzey, C., Uyar, A., \& Delen, D. (2014). The impact of multinationality on firm value: A comparative analysis of machine learning techniques. Decision Support Systems, 59, 127-142.

Lindayani, N. W., \& Dewi, S. K. S. (2016). Dampak Struktur Modal Dan Inflasi Terhadap Profitabilitas Dan Return Saham Perusahaan Keuangan Sektor Perbankan. E-Jurnal Manajemen, 5(8).

Lev, B., \& Sunder, S. (1979). Methodological issues in the use of financial ratios. Journal of Accounting and Economics, 1(3), 187-210. https://doi.org/10.1016/0165-4101(79)90007-7

Lewellen, J. (2004). Predicting returns with financial ratios. Journal of Financial Economics, 74(2), 209-235. https://doi.org/10.1016/j.jfineco.2002.11.002

Misran, M., \& Chabachib, M. (2017). Analisis Pengaruh Der Cr Dan Tato Terhadap Pbv Dengan Roa Sebagai Variabel Intervening (Studi Pada Perusahaan Properti Dan Real Estate Yang Terdaftar Pada Bei Tahun 20112014). Diponegoro Journal Of Management, 6(1), 203-215.

Obreja, I. (2013). Book-to-market equity, financial leverage, and the cross-section of stock returns. The Review of Financial Studies, 26(5), 1146-1189.

Öcal, M. E., Oral, E. L., Erdis, E., \& Vural, G. (2007). Industry financial ratios-application of factor analysis in Turkish construction industry. Building and Environment, 42(1), 385-392. https://doi.org/10.1016/j.buildenv.2005.07.023

Sari, P. R. P., \& Dwirandra, A. A. N. B. (2019). Pengaruh Current Ratio Dan Debt To Equity Ratio Terhadap Profitabilitas Dengan Intellectual Capital Sebagai Pemoderasi. E-Jurnal Akuntansi, 26(2), 851-880.

Triyani, W., Mahmudi, B., \& Rosyid, A. (2018). Pengaruh Pertumbuhan Aset Terhadap Nilai Perusahaan Dengan Profitabilitas Sebagai Variabel Intervening (Studi Empiris Perusahaan Sektor Pertambangan Yang Terdaftar Di Bursa Efek Indonesia Periode 2007-2016). Tirtayasa Ekonomika, 13(1), 107-129. 
Varaiya, N., Kerin, R. A., \& Weeks, D. (1987). The relationship between growth, profitability, and firm value. Strategic Management Journal, 8(5), 487-497.

Widiyanti, M. (2014). Analisis Rasio Likuiditas, Rasio Solvabilitas, Rasio Aktifitas Dan RasioProfitabilitas Pada PT. Holcim Indonesia, Tbk Dan PT. Indocement Tunggal Prakarsa, Tbk. Jurnal Ilmiah Manajemen Bisnis Dan Terapan. Tahun XI, 1, 31-44.

Wiklund, J., Baker, T., \& Shepherd, D. (2010). The age-effect of financial indicators as buffers against the liability of newness. Journal of business venturing, 25(4), 423-437. https://doi.org/10.1016/j.jbusvent.2008.10.011 